\title{
PERAN PEMUDA DALAM MEMBANGUN CITRA PARIWISATA HALAL DI DESA SETANGGOR
}

\author{
Busaini ${ }^{1}$, Baiq Handayani Rinuastuti ${ }^{2}$, Feriyadin ${ }^{3}$, Andrian \\ Wijanarko4, Khairul Amri Assidiq5 ${ }^{5}$ Lalu Ardian Hadinata6, \\ Sintiar Rahmaningsih ${ }^{7}$ \\ 1,2 Faculty of Economics and Business, Mataram University, Indonesia. \\ Email : hrinuastuti@yahoo.com \\ 3,4,5,6,7 Magister Manajemen Fakultas Ekonomi dan Bisnis Universitas Mataram \\ Email: feriyadin@gmail.com
}

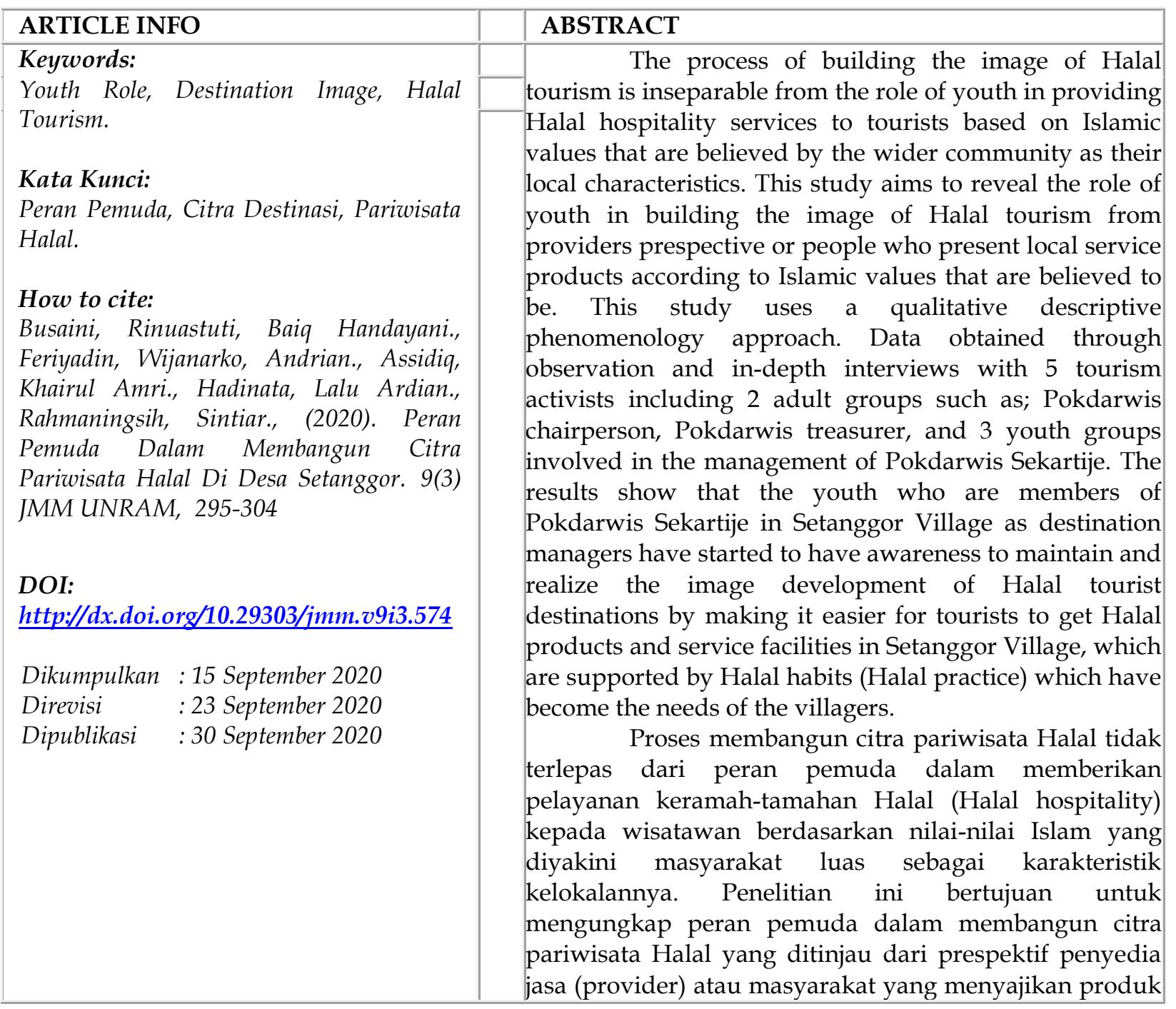




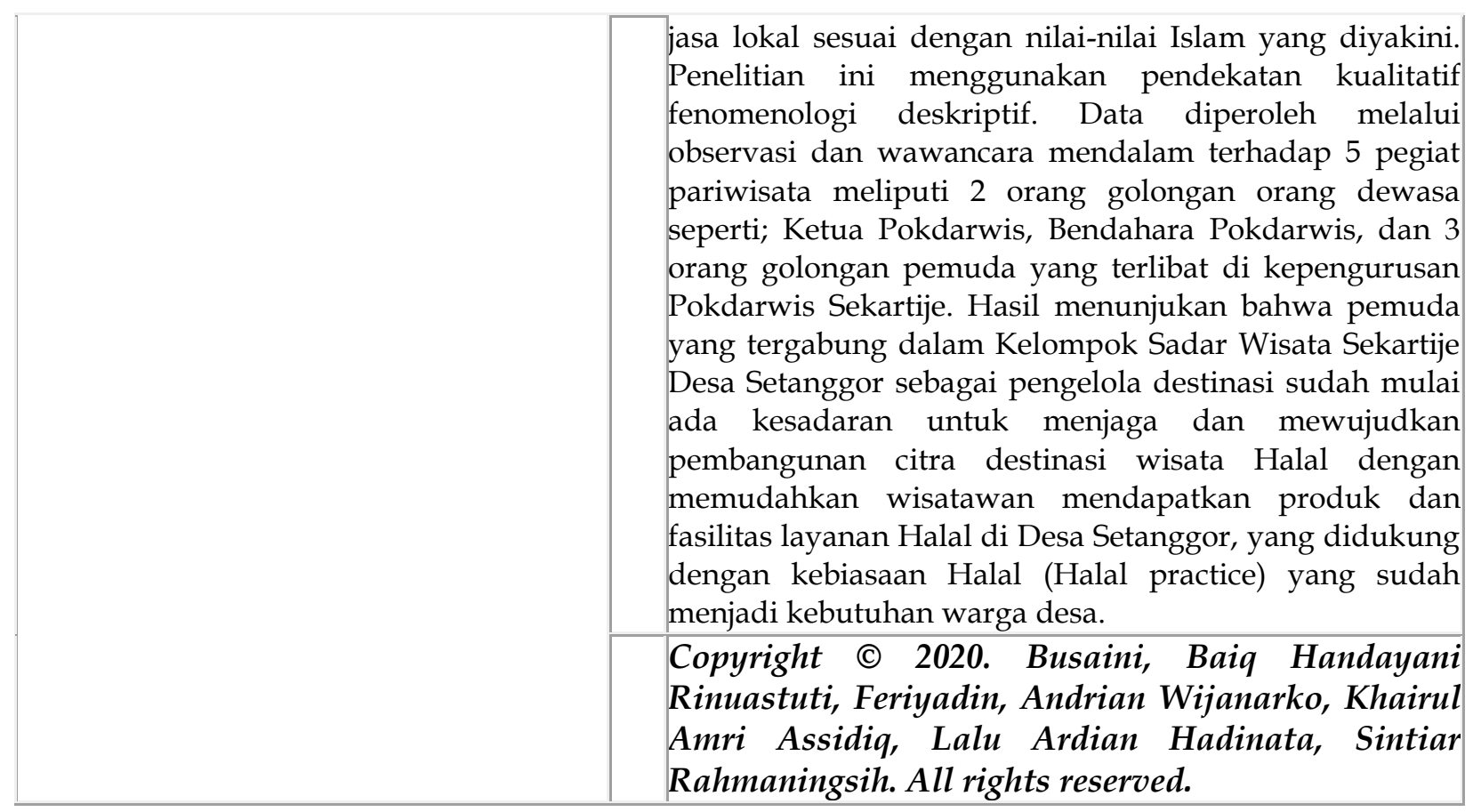

\section{PENDAHULUAN}

Lombok mendapatkan penghargaan dari World Halal Travel Summit yang diselenggarakan di Abu Dhabi selama dua tahun berturut-turut (2015-2016) dengan predikat: destinasi wisata Halal terbaik dunia, pariwisata Halal honeymoon terbaik dunia, serta laman wisata Halal terbaik (Mastercard CrescentRating, 2016). Predikat Halal yang melekat pada pulau Lombok memiliki peluang besar untuk meningkatkan kunjungan wisatawan sekaligus sebagai lokomotif pertumbuhan ekonomi, serta upaya untuk melestarikan kearifan lokal di Pulau Lombok yang terkenal dengan julukan pulau seribu masjid. Perolehan ini memantapkan posisi Lombok dengan kearifan lokal setempat yang kental dengan budaya Islami, tentu memperkuat citra (image) dan karakteristik produk jasa lokal (supply-driven).

Penghargaan yang diperoleh Lombok sebagai destinasi wisata Halal harus dipertahankan dan ditingkatkan (fasilitas dan layanan) agar mampu menarik minat kunjungan wisatawan muslim maupun non-muslim. Karena pariwisata Halal dapat menjadi salah satu motivasi bagi wisatawan non-Muslim yang mencari pengalaman budaya seperti yang selalu dianjurkan World Tourism Organization (WTO) (Battour, Ismail \& Battor, 2010). Oleh karena itu, diperlukan strategi pemasaran destinasi wisata supaya branding pariwisata Halal masif diketahui oleh penyedia jasa dan wisatawan. Faktor terpenting dalam strategi pemasaran pariwisata Halal adalah citra destinasi (destination image). Dimana citra destinasi wisata memiliki peran penting untuk keberhasilan suatu destinasi wisata karena memberikan efek multidimensi bagi wisatawan maupun masyarakat lokal untuk pembuatan keputusan tujuan wisata (Al-Kwifi, 2015).

Sebagai bentuk kesiapan pemerintah daerah dalam menjaga dan membangun citra pariwisata Halal di Lombok, yaitu membentuk 99 desa wisata di Lombok-Sumbawa (ntbprov.go.id, 2019). Salah satu desa wisata yang menjadi pilot project di pulau Lombok adalah Desa Setanggor. Desa ini merupakan desa wisata yang menawarkan keunikan budaya yang dipadukan dengan nilai-nilai Islami. Para pengelola wisata menyuguhkan 
atraksi wisata Halal seperti "mengaji ditengah sawah" berupa mengajak para wisatawan untuk belajar membaca Al-Qur'an di tengah sawah. Atraksi ini menarik minat para wisatwan dari Malaysia, Brunei Darussalam hingga wisatawan asal Timur-Tengah lainnya. Harapannya, keunikan dan kelokalan yang terdapat di desa tersebut dapat disuguhkan sesuai dengan kearifan lokal yang ada di Desa Setanggor.

Sumber daya manusia lokal terutama pemuda sebagai bagian dari masyarakat yang menyediakan produk jasa lokal sangat penting dalam pembangunan wisata ini. Karena pemuda adalah bagian dari masyarakat lokal yang mesti diikutsertakan dalam pengembangan pariwisata (Swasono, 2013) khususnya dalam membangun citra pariwisata Halal. Akan tetapi penelitian Herayomi (2016) menunjukan hasil yang berbeda yaitu Peran pemuda dalam mengembangkan desa wisata adalah sebagai obyek, bukan sebagai subyek. Misalnya Tidak terdapat partisipasi pemuda dalam pembuatan dan pengambilan keputusan dalam rencana-rencana yang biasa direncanakan, hal ini ditandai bahwa inisiatif setiap program dan kegiatan tidak muncul dari pemuda tapi dari pengurusnya, terutama dalam membangun citra pariwisata Halal di Desa Setanggor

Uraian hasil penelitian diatas menunjukkan bahwa pemuda memiliki peran yang sangat strategis dalam hal apapun, seperti; penghubung antara kearifan lokal dengan kebutuhan wisatawan (Herayomi, 2016), memberikan pengalaman baru bagi setiap wisatawan dengan menyuguhkan wisata mengaji di tengah sawah (Adinugraha, Sartika \& Kadarningsih, 2018), dan membangunan citra pariwisata Halal. Sehingga peneliti tertarik untuk melakukan sebuah penelitian dengan judul Peran Pemuda Dalam Membangun Citra Pariwisata Halal di Desa Setanggor. Penelitian ini penting dilakukan dengan harapan bisa mengungkap peran pemuda dalam membangun citra pariwisata Halal, yang ditinjau dari prespektif penyedia jasa (provider) atau masyarakat yang menyajikan produk jasa lokal. Karena dari sejumlah penelitian yang telah disebutkan diatas, belum ada secara spesifik penelitian yang mengkaji bagaimana pemuda berperan dalam membangun citra pariwisata Halal.

\section{KAJIAN PUSTAKA}

\subsection{Peran Pemuda dalam Konteks Pariwisata}

Generasi muda, mesti mengambil peran sentral dalam berbagai bidang untuk membangun bangsa dan Negara, khususnya pada sektor pariwisata (Hiryanto, Wibawa \& Rohadi, 2015). Hal ini disadari bahwa pemuda sebagai bagian dari masyarakat lokal pastinya harus diikutsertakan dalam pengembangan pariwisata (Swasono, 2013) yang akan memberikan manfaat dan kemaslahatan kehidupan.

Oleh karena itu, peran konkrit masyarakat tuan rumah khususnya pemuda dalam pengembangan pariwisata sangat penting, karena mereka dapat memberikan penjelasan mengenai potensi dan keunikan yang dimiliki desanya dalam memajukan perekonomian masyarakat serta bertanggung jawab dalam menjaga eksistensi kearifan lokal yang ada di desanya.

\subsection{Pariwisata Halal}

Pemerintah Provinsi Nusa Tenggara Barat merumuskan sebuah definisi rumusan pariwisata Halal yang akan dikembangkan melalui Perda No. 2 Tahun 2016 bahwa pariwisata Halal merupakan kegiatan kunjungan wisata dengan destinasi dan industri pariwisata yang menyiapkan fasilitas produk, pelayanan, dan pengelolaan pariwisata yang memenuhi syariah. 
Sementara itu, menurut Battour \& Ismail (2016) bahwa pariwisata Halal mengacu pada "objek atau tindakan pariwisata apa pun yang diizinkan menurut ajaran Islam untuk digunakan atau dilibatkan oleh umat Islam dalam industri pariwisata". Nilai syariat Islam sebagai suatu kepercayaan dan keyakinan yang dianut umat Muslim menjadi acuan dasar dalam membangun kegiatan pariwisata. Halal ini diatur untuk memudahkan para wisatawan Muslim dalam berkegiatan wisata baik di negera muslim maupun negara yang secara populasi penduduk muslimnya sedikit (Battour \& Ismail, 2016; Jafari \& Scott, 2014). Sejalan dengan definisi tersebut, Menteri Pariwisata Arif Yahya juga menerangkan bahwa:

"Pariwisata Halal adalah sama seperti pariwisata pada umumnya hanya menyiapkan

Extended Service (layanan tambahan) bagi wisatawan muslim. Secara generik,

Pariwisata Halal diantaranya adalah dapat berupa wisata alam, wisata budaya, maupun wisata buatan dalam bingkai wisata keluarga (Halal lifestyle)". (Djakfar, 2017).

Dari penjelasan tentang pariwisata Halal diatas, pemerintah Provinsi Nusa Tenggara Barat menyadari bahwa potensi pengembangan pariwisata Halal sebagai branding dalam pengembangan dan pengelolaan pariwisata daerah bertujuan untuk meningkatkan jumlah kunjungan wisatawan muslim yang akan berkunjung ke Lombok melalui penyediaan layanan ramah muslim, baik itu disektor industri maupun destinasi.

\subsection{Citra Destinasi}

Citra destinasi adalah gabungan produk dan atribut yang disusun menjadi kesan yang lengkap (Kim, 2014). Selanjutnya citra destinasi berperan penting dalam pemilihan destinasi, proses pengambilan keputusan dan pemilihan kegiatan di destinasi seperti akomodasi, atraksi yang akan dikunjungi, kegiatan untuk berpartisipasi dalam kegiatan wisata, perilaku, termasuk pengalaman di destinasi, evaluasi dan loyalitas untuk destinasi tertentu (Chen \& Tsai, 2007).

Wisatawan akan membandingkan citra destinasi wisata yang dimilikinya dengan pengalaman langsung selama berkunjung ke suatu destinasi wisata. Jika pengalaman nyata yang dialami wisatawan sesuai atau melebihi harapan maka wisatawan akan merasa puas, menjadi loyal, melakukan kunjungan ulang, dan merekomendasikannya kepada orang lain (Akroush, Jraisat, Kurdieh, Al-Faouri, \& Qatu, 2016; Allameh, Pool, Reza, \& Asadi, 2015; Al-Kwifi 2015; Assaker, Vinzi \& O'Connor, 2011; Greaves \& Skinner, 2010; Chen \& Tsai, 2007).

Citra tentang suatu tempat (destinasi wisata) tidak hanya dimiliki oleh wisatawan tetapi juga oleh penduduk lokal. Oleh karenanya pemahaman terhadap sikap dan pandangan dari para stakeholder (termasuk penduduk lokal) menjadi suatu hal yang penting dalam perencanaan dan pengelolaan pariwisata yang berkelanjutan (Kemp, Williams, \& Bordelon, 2011; Byrd, Bosley, \& Dronberger, 2009).

\section{METODOLOGI PENELITIAN}

Peneliti menggunakan metode kualitatif, yaitu dimana peneliti memahami masalah mendasar dan menggambarkan secara sistematis dan jelas tentang situasi-situasi sosial atau fenomena dilokasi (Mulyadi, 2012) dan guna memandang, memahami serta melihat keadaan masyarakat khususnya pemuda Desa Setanggor. Pengumpulan data diperoleh melalui observasi dan wawancara mendalam terhadap 5 pegiat pariwisata meliputi 2 orang golongan orang dewasa seperti; Ketua Pokdarwis, Bendahara Pokdarwis, dan 3 orang golongan pemuda yang terlibat di Kepengurusan Pokdarwis Sekartije. Untuk 
mendapatkan informasi ditentukan dengan purposive sampling. Data yang diperoleh kemudian dilakukan reduksi data, penyajian data, verifikasi dan penarikan kesimpulan (Miles \& Huberman, 2009).

\section{HASIL DAN PEMBAHASAN}

\subsection{Dari Desa Biasa Menjadi Desa Wisata}

Terbentuknya Desa Setanggor menjadi destinasi wisata awalnya tidak terlepas dari keinginan untuk membangun desa yang dilakukan para pemuda desa yang aktif berkegiatan wisata di luar desa. Sebagaimana dijelaskan Mahruf selaku Ketua Kelompok Sadar Wisata Sekartije Desa Setanggor bahwa:

"....justru pemuda yang bekerja diluar desa inilah yang memberikan pengarahan dan bimbingan kepada warga desa disini tentang pariwisata. Pada awalnya para orang tua menganggap ide pemuda ini gila, tetapi setelah ada wisatawan asing yang berkunjung ke desa untuk melihat alam persawahan dan budaya yang ada, baru warga desa sadar bahwa Desa Setanggor bisa dikemas menjadi desa wisata"

Jauh sebelum Desa Setanggor menjadi desa wisata, masyarakat desa sudah terlebih dahulu aktif mengembangkan dan melestarikan budaya Sasaq seperti tari-tarian, nyenseq (menenun), ritual pernikahan adat Sasaq, pembacaan lontar, hingga pagelaran alat musik tradisional berupa Gong (Gamelan) dan drama dari Desa Setanggor ini sudah terkenal dan diundang untuk pentas diberbagai desa yang ada di pulau Lombok.

Peran masyarakat dalam melestarikan budaya peninggalan leluhur inilah yang kemudian mendorong sosok perempuan bernama Ida Wahyuni bersama pemuda desa lainnya berjuang menggerakkan masyarakat setempat untuk mengembangkan budaya lokal yang ada menjadi daya tarik wisata yang akan disuguhkan kepada para wisatawan ketika berkunjung ke Desa Setanggor. Kehadiran pemuda dalam membangkitkan semangat masyarakat untuk tetap melestarikan budaya peninggalan juga diharapkan mampu menambahkan pendapatan keluarga melalui terbentuknya desa wisata.

Setiap pengembangan dan perubahan ke arah positif senantiasa melibatkan pemuda, seperti halnya kegiatan sosialisasi pariwisata untuk memberikan pencerahan kesadaran kepada warga desa, sebagaimana dijelaskan Ida Wahyuni, salah satu inisiator desa wisata Setanggor bahwa tantangan awal ialah mengubah pola pikir (mindset) masyarakat yang khawatir akan dampak negatif dari adanya pariwisata.

Namun, setelah diberikan penjelasan terkiat pentingnya membentuk desa wisata dengan potensi-potensi yang dimiliki oleh budaya masyarakat setempat serta solusi yang ditawarkan untuk menepis munculnya sesuatu yang dikhawatirkan masyarakat yaitu dengan menerapkan konsep pariwisata Halal untuk meminimalisir pengaruh-pengaruh nagatif dari para wisatawan. Ida juga menjelaskan bahwa:

"Setiap wisatawan yang berkunjung ke desa wisata Setanggor harus mematuhi aturanaturan dan adat istiadat yang berlaku di desa. Seperti harus mengenakan kain untuk menutup aurat bagi wisatawan dan tidak boleh meminum-minuman beralkohol selama berada di Desa Setanggor" (Saleh - Bendahara Pokdarwis, Golongan orang dewasa)

\subsection{Upaya Pemuda Dalam Membangun Citra Destinasi Wisata Halal}

Perkembangan desa wisata Setanggor dari awal pembentukan lebih fokus ke pelestarian budaya lokal sebagai produk atraksi wisata yang ditawarkan kepada pengunjung mulai berkembang dengan memanfaatkan potensi alam persawahan yang ada di desa sebagai atraksi wisata. Para pemuda yang tergabung dalam kelompok sadar wisata 
bersama dengan masyarakat dusun menyiapkan lahan persawahannya untuk menanam tanaman seperti padi, singkong, pisang dan dijadikan sebagai atraksi layanan tambahan bagi para wisatawan yang ingin belajar bertani dan berkebun.

Selain itu, para pemuda desa juga mengelola alam persawahan desa sebagai destinasi wisata Halal yang menarik kunjungan wisatawan muslim berupa atraksi "Ngaji di tengah sawah" dengan maksud untuk mengajak para wisatawan belajar membaca AlQur’an di tengah sawah. Guru ngaji juga sudah disiapkan oleh para pemuda pengelola yang merupakan alumni dari pondok pesantren yang ada di pulau Lombok. Selain paket wisata alam tersebut, pengelola desa wisata juga menyiapkan paket belajar budaya lokal seperti, tari-tarian, gong dan gamelan, ritual pernikahan adat Sasaq, hingga proses pembuatan kain tenun khas suku Sasaq berbahan alam.

Selanjutnya, dalam proses pelayanan yang dilakukan para pemuda desa yang tergabung dalam Kelompok Sadar Wisata Sekartije terhadap para tamu yang tiba di desa yakni disambut dalam pos-center penyambutan dan diberikan pengarahan oleh pengelola desa wisata kemudian dipakaikan kain tenun yang dibuat oleh masyarakat setempat kepada wisatawan untuk menutup aurat. Setelah itu, para wisatawan melakukan kunjungan ke tempat-tempat yang sudah disiapkan oleh para pengelola.

Pada awalnya kehadiran para wisatawan asing ini menjadi kekhawatiran warga desa karena takut jika kebiasaan-kebiasaan buruk wisatawan seperti berpakaian mini dan minum minuman beralkohol akan ditiru oleh para generasi muda dan warga desa. Akan tetapi, kekhawatiran tersebut mampu ditanggulangi oleh para pemuda pengelola wisata dengan memberikan layanan tambahan berupa mengenakan pakaian tenun tradisional yang dibuat warga desa sebagai pakaian untuk menutup aurat bagi para wisatawan. Hal ini pun, semakin membuat para wisatawan khususnya wisatawan asing semakin tertarik karena mendapat pengalaman berbeda dengan destinasi wisata lainnya.

Pelayanan ketika awal tamu datang ke desa tersebut sudah mencerminkan unsurunsur pelaksanaan wisata Halal baik itu untuk wisatawan muslim maupun non muslim. Aturan mengenakan pakaian tradisional untuk menutup aurat yang disuguhkan kepada para wisatawan tersebut harus dipatuhi oleh setiap travel agent yang mengambil paket kunjungan wisata ke desa wisata Setanggor, karena penduduk Desa Setanggor merupakan warga muslim secara keseluruhan. Dengan demikian, peran pemuda desa wisata Setanggor dalam mengelola desanya saat ini sudah mulai dikembangkan dengan memperhatikan kebutuhan wisatawan muslim. Meskipun baru memulai untuk menerakan konsep-konsep syariah dalam pelayanan dan pengelolaannya, akan tetapi sudah mulai ada kesadaran dari para pemuda sebagai pengelola destinasi wisata. Sehingga, untuk mendapatkan produk dan fasilitas layanan wisata Halal di desa ini sangat mudah didapatkan, disamping kebiasaan Halal (Halal practice) sudah menjadi kebutuhan warga desa.

Nilai-nilai Islami sebagai dasar dalam menjalani kehidupan dan keseharian masyarakat sebagai tuan rumah dalam segala aktivitasnya penting diyakini pemuda untuk mengelola pariwisata, karena salah satu yang dapat membangun citra destinasi yakni menunjukan perilaku keramah-tamahan Halal (Halal hospitality) tuan rumah dalam berinteraksi dengan wisatawan baik itu untuk wisatawan muslim maupun non muslim.

"Kami menyadari bahwa perilaku itu kan masuk dalam kategori pelayanan dan itu yang akan menarik perhatian wisatawan juga, ketika kita memberikan pelayanan yang terbaik dengan cara yang baik, ....mengutamakan interaksi yang positif dengan cara menunjukan keramah tamahannya sopan santunnya, tanggung jawab terhadap tamu, mendahulukan mereka, selalu mengatakan hal yang positif, itu yang kami terus 
upayakan kepada wisatawan dan Alhamdulillah banyak yang terkesan dengan cara-cara seperti itu sehingga citra desa tetap terjaga"(Fatma - anggota Pokdarwis Sekartije sekaligus sebagai pemandu lokal, kalangan Pemuda).

Hubungan baik antara tuan rumah dan tamu adalah kunci dalam memberikan pengalaman wisatawan dan membangun citra yang baik bagi destinasi yang dikunjungi. Oleh karena itu, jantungnya pariwisata ada pada perilaku interaksi positif antara tuan rumah dan tamu.

"Kita harus ramah, tebar senyum, sapa wisatawannya, dan terus tunjukan sopan santun. Pentingnya menjaga hubungan baik dengan orang lain kami dapatkan dari ajaran-ajaran dalam agama kami, dan orang-orang tua kami mengajarkan itu juga dengan menunjukkan cara hidup yang baik sehingga kami sudah memiliki contoh teladan dari orang tua, bagaimana semestinya harus bersikap dengan orang tua maupun orang yang baru, kami harus menjaga perasaannya, seperti itu disampaikan oleh orang tua-orang tua kami dan mereka menunjukkan itu juga dalam perilakunya. Itu telah menjadi kebiasaan kita juga"(Isna - anggota Pokdarwis Sekartije sekaligus sebagai ketua Bumdes, kalangan Pemuda).

Potensi yang dikemukakan para pegiat pariwisata ini menekankan pada posisi dan peran mereka selaku penyedia jasa pariwisata. Ajaran Islam mewajibkan masyarakat tuan rumah untuk bersikap baik kepada wisatawan, dan menyediakan pelayanan terbaik untuk mereka, dengan rasa suka cita sebagai tanda dan wujud dari kekuatan iman (Kirillova, Gilmetdinova, Lehto, 2014; Siddiqui, 2015).

"Namanya tamu itu adalah raja kita layani mereka dengan baik Namun kami juga tidak boleh melepas cara-cara kami yang diajarkan di Islam tetap mengutamakan pelayanan sesuai dengan syariat kami" (Nurjannah - anggota Pokdarwis Sekartije, kalangan Pemuda)

Hal ini perlu diperhatikan oleh penyedia jasa Muslim untuk memperoleh pemahaman tentang kebutuhan wisatawan yang ingin mendapatkan keaslian pengalaman (authentic experience) dan kerahmah-tamahan secara spiritual (Salleh, Hamid, Hashim \& Omain, 2014) Sehingga penyedia jasa perlu menyadari pentingnya prinsip-prinsip agama (religiusitas) sebagai rujukan dalam berinteraksi dan melayani tamu untuk membangun citra destinasi yang positif baik bagi masyarakat tuan rumah maupun wisatawan.

Berdasarkan temuan dalam studi ini, terdapat beberapa peran yang dilakukan pemuda dalam rangka membangun Desa Setanggor menjadi Desa Wisata Halal yakni sebagai berikut :

1. Kesadaran pemuda untuk menjaga kebersihan lingkungan hingga mengajak masyarakat terlibat aktif untuk menjaga kenyamanan bagi wisatawan.

2. Pemuda berperan aktif dalam mengembangkan desa wisata Setanggor. Para pemuda juga bersedia mengeluarkan iuran untuk pembuatan papan informasi desa wisata Setanggor.

3. Pemuda berperan aktif mendukung dan menggerakkan masyarakat dalam kegiatankegiatan hari besar keagamaan.

4. Pemuda berperan aktif menjaga kelangsungan budaya dalam bentuk berpartisipasi aktif diacara ritual pernikahan pemuda desa dengan semangat gotong-royong.

5. Para pemuda masih menjaga aturan adat (awiq-awiq desa) bahwa pemuda laki-laki dan perempuan sakral untuk bersama-sama pada malam hari sampai jam-jam tertentu.

6. Para pemuda juga terlibat aktif sebagai personil tim gamelan desa dan sudah mempunyai kelompok tersendiri sebagai pendukung paket wisata yang sudah disiapkan. 
7. Para pemuda yang bekerja sebagai guide di desa wisata Setanggor selalu memberikan permakluman/himbauan kepada para wisatawan bahwa setiap wisatawan yang berkunjung harus memakai pakaian yang menutup aurat atau tidak menggunakan pakaian yang mini.

8. Dalam hal apabila wisatawan yang sedang berkegiatan berkeliling desa dan waktu sholat sudah tiba, para guide lokal bertugas mengingatkan dan menghentikan kegiatan wisatawan untuk menunaikan sholat.

9. Para pemuda yang perperan sebagai pengelola homestay diharuskan bersikap jujur, ramah, dan selalu mengedepankan etika dalam melayani para wisatawan.

10. Para pemuda lokal sebagai masyarakat tuan rumah menunjukan pelayanan keramahtamahan Muslim kepada tamu yang seagama maupun tamu yang berbeda agama sesuai kearifan lokal Islami yang diyakini.

\subsection{Tantangan Pemuda Dalam Meningkatkan Citra Destinasi Wisata Halal}

Dari hal tersebut diatas, maka beberapa hal yang perlu dikembangkan oleh para pemuda desa wisata Setanggor untuk meningkatkan pengelolaan destinasi wisata Halal di Desa Setanggor berupa:

1. Proses perencanaan setiap kegiatan di desa belum memberikan porsi lebih banyak kepada para pemuda untuk berperan aktif dalam mengembangkan desa wisata.

2. Memberikan pelatihan kepada para pemuda tidak hanya dalam bidang budaya, tapi juga dalam bidang keagamaan untuk meningkatkan kesadaran pemuda terhadap pentingnya keseimbangan antara budaya, agama, dan pariwisata.

3. Pemuda harus mampu mensosialisasikan secara intensif terkait konsep pembangunan desa wisata Halal karena belum banyak masyarakat yang mengenal istilah wisata Halal yang saat ini sedang di kembangkan di Desa Setanggor.

4. Masih minimnya para pemuda desa yang mau menjadi guide lokal para wisatawan merupakan tantangan tersendiri bagi kelompok sadar wisata yang harus segera disikapi keberlanjutan pengelolaan desa wisata.

5. Masih minimnya perjumpaan regular (tatap muka) oleh pengurus senior dan pemuda yang tergabung dalam Kelompok Sadar Wisata Sekartije untuk menyatukan persepsi tentang arah pembangunan pariwisata di Desa Setanggor.

\section{KESIMPULAN DAN SARAN}

\subsection{Kesimpulan}

Pemuda merupakan kekuatan dan aset dalam membangun citra pariwisata Halal di Desa Setanggor, mereka mempunya peran strategis dalam proses pembangunan desa. Pemuda yang tergabung dalam Kelompok Sadar Wisata Sekartije Desa Setanggor sebagai pengelola destinasi sudah mulai ada kesadaran untuk menjaga dan mewujudkan pembangunan citra destinasi wisata Halal dengan memudahkan wisatawan mendapatkan produk dan fasilitas layanan wisata Halal di Desa Setanggor yang didukung dengan kebiasaan Halal (Halal practice) yang sudah menjadi kebutuhan warga desa. Adapun peran yang dilakukan pemuda yakni :

1. Kesadaran pemuda menjaga kebersihan lingkungan untuk menjaga kenyamanan bagi wisatawan.

2. Pemuda berperan aktif dalam mengembangkan wisata bahkan bersedia mengeluarkan iuran untuk pembuatan papan informasi wisata dan juga menggerakkan masyarakat dalam kegiatan-kegiatan hari besar keagamaan. 
3. Pemuda berperan aktif menjaga kelangsungan budaya, semangat gotong-royong dan sangat menjaga aturan adat (awiq-awiq desa).

4. Para pemuda mempunyai kelompok tersendiri sebagai pendukung paket wisata yang sudah disiapkan.

5. Para pemuda yang bekerja sebagai guide di desa wisata Setanggor juga bertugas mengingatkan dan menghentikan kegiatan wisatawan apabila waktu sholat tela tiba dan juga memerikan himbawan kepada setiap wisatawan yang berkunjung harus memakai pakaian yang menutup aurat atau tidak menggunakan pakaian yang mini.

6. Para pemuda yang perperan sebagai pengelola homestay diharuskan bersikap jujur, ramah, dan selalu mengedepankan etika dalam melayani para wisatawan begitu juga dengan masyarakat yang berperan sebagai tuan rumah harus menunjukan perilaku keramah-tamahan Halal (Halal hospitality) dalam berinteraksi dengan wisatawan baik itu untuk wisatawan muslim maupun non muslim.

\subsection{Saran}

Sebagaimana diterangkan dalam kesimpulan diatas bahwa para pemuda desa yang tergabung dalam Pokdarwis Sekartije Desa Wisata Setanggor sudah berhasil mewujudkan pembangunan citra destinasi wisata Halal Desa Setanggor. Akan tetapi masih terdapat tantangan yang harus dituntaskan segera untuk mempercepat peningkatan pembangunan citra wisata Halal di Desa Setanggor seperti: Pertama, para pemuda yang tergabung dalam Kelompok Sadar Wisata Sekar Tije perlu menjaga konsistensi pemuda untuk tetap melestarikan budaya Sasaq dengan memperbanyak kegiatan untuk pemuda. Kedua, memberikan porsi lebih banyak kepada para pemuda untuk berperan aktif dalam perencanaan sampai evaluasi setiap kegiatan di desa. Ketiga, memberikan pelatihan kepada para pemuda tidak hanya dalam bidang budaya tapi juga dalam bidang keagamaan untuk meningkatkan kesadaran pemuda terhadap pentingnya keseimbangan antara budaya, agama, dan pariwisata.

\section{DAFTAR PUSTAKA}

Adinugraha, H.H., Sartika, M., \& Kadarningsih, A. (2018), “Desa Wisata Halal: Konsep dan Implementasinya di Indonesia)", Human Falah, Volume 5, No. 1.

Akroush, M., Jraisat, L., Kurdieh, D., Al-Faouri, R., \& Qatu, L. (2016), “Tourism service quality and destination loyalty - the mediating role of destination image from international tourists' perspectives" Tourism Review, pre-printed version.

Al-Kwifi, O.S. (2015), "The impact of destination images on tourists' decision making", Journal of Hospitality and Tourism Technology.

Allameh, S., Pool, J., Reza, A., \& Asadi, S. (2015), "Factors influencing sport tourists' revisit intentions" Asia Pacific Journal of Marketing and Logistics.

Assaker, G., Vinzi, V., \& O'Connor P. (2011), “Examining The Effect of Novelty Seeking, Satisfaction, and Destination Image on Tourist' Return Pattern: a Two Factor, Nonlinear Latent Growth Model", Tourism Management, 32 (4), 890-901.

Battour, M., \& Ismail, M.N. (2016), "Halal tourism: Concepts, practices, challenges and future", Tourism Management Perspectives, 19, 150-154.

Battour, M.M., Ismail, M.N., \& Battor, M. (2010), "Toward a Halal tourism market”, Tourism Analysis, 15 (4), 461-470. 
Byrd, E.T., Bosley, H.E. \& Dronberger, M.G. (2009), “Comparisons of stakeholder perceptions of tourism impacts in rural eastern North Carolina", Tourism Management, Vol. 30 No. 5, pp. 693-703.

Chen, C., \& Tsai, D. (2007), "How destination image and evaluative factors affect behavioral intentions?", Tourism Management.

Djakfar, M. (2017), Peta Jalan Menuju Pengembangan Akademik \& Industri Halal di Indonesia, Malang: UIN-Maliki Press.

Gigih Swasono Perdana Putra. (2013), "Partisipasi Pemuda dalam Pengembangan Agrowisata Di Desa Berjo, Ngargoyoso, Karang anyar".

Greaves, N., \& Skinner, H. (2010), "The importance of destination image analysis to UK rural tourism. Marketing Intelligence $\mathcal{E}$ Planning.

Herayomi, I. (2016), “Peran Pemuda dalam Pengembangan Desa Wisata Kebon Agung, Imogiri, Bantul, Daerah Istimewa Yogyakarta". Jurnal Elektronik Pendidikan Luar Sekolah (E-Diklus).

Hiryanto, Wibawa, L., \& Rohadi A.S. (2015), "Pengembangan Model Pelatihan Kepemimpinan Bagi Organisasi Kepemudaan di Daerah Istimewa Yogyakarta", Jurnal Penelitian Ilmu Pendidikan, Volume 8, Nomor 2.

Jafari, J., \& Scott, N. (2014), "Muslim world and its tourisms”, Annals of Tourism Research, 44, 119.

Kemp, E., Williams, K.H. \& Bordelon, B.M. (2011), “The impact of marketing on internal stakeholders in destination branding: the case of a musical city" Journal of Vacation Marketing, Vol. 18 No. 2, pp. 121-133

Kim, J.H. (2014), “The Antecedents of Memorable Tourism Experience: The Deveopment of a scale to Measure The Destination Attributes Associated with Mmorable Experiences", Tourism Management, Vol. 44: 34-45.

Kirillova, K., Gilmetdinova, A., Lehto, X., (2014), "Interpretation of hospitality across religions", Int. J. Hosp. Manage. 43, 23-34.

MasterCard and CrescentRating. (2016). Global Muslim Travel Index (GMTI) 2016, di unduh 24 Mei 2020, dari https://www.crescentrating.com/reports/mastercardcrescentrating-global-Muslim-travel-index-gmti-2016.html

Miles, M.B, \& Huberman, A.M. (2009), Analisis Data Kualitatif. Terjemahan: Tjetjep Rohendi Rohidi, Jakarta: UI Press.

Mulyadi (2012), Penelitian Kuantitatif \& Kualitatif Serta Praktek Kombinasinya dalam Penelitian Sosial, Publica Institute; Jakarta.

NTB Prov, (2019), Tetapkan 99 Desa, Pemprov Awali Dengan 25 Desa Wisata, diunduh 30 September, 2020, dari https://www.ntbprov.go.id/post/tetapkan-99-desapemprov-awali-dengan-25-desa-wisata

Peraturan Daerah Provinsi Nusa Tenggara Barat Nomor 2 Tahun 2016 Tentang Pariwisata Halal.

Salleh, N.Z.M., Hamid, A.B.A., Hashim, N.H., \& Omain, S.Z. (2014). The practice of shariah-compliant hotel in Malaysia. International Journal of Trade, Economics and Finance, 5(1), 26-30.

Siddiqui, M., (2015), Hospitality and Islam: Welcoming in God's Name. Yale University Press. 